\title{
ИССЛЕДОВАНИЕ ЭМОЦИОНАЛЬНОЙ СФЕРЫ БОЛЬНЫХ САХАРНЫМ ДИАБЕТОМ 2 ТИПА
}

\author{
Русина Н.А., Буйдина Т.А., Липкина А.И. \\ ФГБОУ ВО «Ярославский государственный медицинский университет», \\ чуз Клиническая больница «РЖД-Медицина», г. Ярославль
}

ЦЕль: исследование эмоциональной сферы больных сахарным диабетом 2-го типа для определения психотерапевтических мишеней.

МАТЕРИАЛЫ И МЕТОДЫ: 102 человека обоего пола: 52 пациента с СД 2 типа с показателями гликированного гемоглобина 7,3+-0,9\%, давностью заболевания до 10 лет и 50 человек группы сравнения, аналогичных больным с СД по коморбидным заболеваниям и состояниям (артериальная гипертензия, ожирение, дислипидемия), возраст 44-65 лет. Применялись опросник «Запрет на выражение чувств» (Зарецкий В.К., Холмогорова А.Б., Гаранян Н.Г.); опросник на изучение перфекционизма (Гаранян Н.Г., Холмогорова А.Б.), шкала дифференциальных эмоций К. Изарда (в адаптации Леоновой А.Б.).

PЕзУЛЬтАТЫ: У больных с СД выявлено наличие завышенных притязаний и требований по отношению к себе, ориентация на высокие результаты деятельности, детальное планирование деятельности, стремление сравнивать себя с другими людьми, что подтверждает общий высокий показатель перфекционизма. Результаты корреляций доказали значительные взаимосвязи по всем шкалам перфекционизма и общего запрета выражения чувств у больных с СД в отличие от пациентов группы сравнения, что свидетельствует о более жесткой структуре показателей изучаемых факторов у них. Такие результаты характеризуют больных с СД как более ригидных в выражении своих чувств, как личностей, стремящихся проявлять перфекционизм на всех уровнях жизнедеятельности. Можно говорить, что пациенты с СД стремятся подавлять свои эмоции, у них наблюдается более сильное волевое управление эмоциями, нежели у группы сравнения.

Следует отметить, что результаты корреляций показали у больных с СД высокий уровень различных взаимовлияний как при исследовании перфекционизма, так и в исследовании подавления чувств. Для больных с СД самыми сильными запретными чувствами являются гнев и страх. Для них очень важно не показывать свои промахи и неудачи, требовать высоких результатов от себя и от других, при этом они запрещают себе проявлять отрицательные негативные сильные чувства, что может приводить к резкому подъему сахара крови в стрессовых ситуациях, в ситуациях оценки. Парадоксально, что общий запрет на выражение чувств у этих больных в большей степени обеспечивается запретом на выражение радости: больные не умеют радоваться даже мелочам, поскольку очень высоки их высокие стандарты деятельности.

В исследовании получены данные о том, что индекс положительных эмоций у больных с СД ниже, чем у группы сравнения. Также было выявлено, что индекс тревожно-депрессивных эмоций у них выше. Это может говорить о том, что для больных характерны выраженная тревожность, депрессивность, сниженный фон настроения. Показатели интереса и эмоциональной насыщенности жизни у группы сравнения значительно выше, чем у пациентов с СД.

ВывОды: Индекс тревожно-депрессивных эмоций и индекс отрицательных эмоций значимо выше у больных СД; индекс положительных эмоций выше у пациентов группы сравнения. Пациенты СД проявляют перфекционизм на всех уровнях жизнедеятельности, стремятся подавлять свои эмоции. Самыми сильными запретными чувствами для них являются гнев и страх. Общий запрет на выражение чувств у больных СД в большей степени обеспечивается запретом на выражение радости. Данное исследование расширяет знания врачей по психологии пациентов с СД 2 типа.

КЛЮЧЕВЫЕ СЛОВА: сахарный диабет 2 типа, подавление эмоций, перфекционизм Цель: исследование проявления эмоций у пациентов с сахарным диабетом (СД) 2 типа для определения психотерапевтических мишеней. 